\title{
Environmental Sanitation Factors Associated With Intestinal Parasitic Infections In Primary School Children In Elengaz, Khartoum, Sudan.
}

\author{
Abdelsafi A Gabbad ${ }^{1}$ and Mohammed A Elawad ${ }^{2}$ \\ Dept of Public Health, College of Health Sciences at Alith, Umm Alqura University, Saudi Arabia \\ Dept of Public Health, College of Health Sciences at Alith, Umm Alqura University,Saudi Arabia
}

\begin{abstract}
A cross sectional study was conducted on environmental sanitation factors associated with intestinal parasitic infections in primary school children in Elengaz, Khartoum, Sudan. About 500 children were selected from four primary schools by systemic random sample. Stool specimens were collected and examined by microscope in order to detect intestinal parasite infections. Data about environmental sanitation and water supply were obtained from children parents. Lack of access to potable water (Odds ratio $=5.8,95 \% \mathrm{CI}=3.8$ to 8.9), Unsanitary solid waste disposal (Odds ratio $=1.6,95 \% \mathrm{CI}=1.1$ to 2.3), lack of latrine in the family house (Relative risk $=3.9,95 \% C I=2.7$ to 4.3$)$ and overcrowded living $(P$-value $=0.004)$ were factors associated with intestinal parasitic infections. Improvement of water supply and sanitation is a fundamental issue in controlling intestinal parasitic infections.
\end{abstract}

Key words: sanitation, intestinal, parasitic, children, water.

\section{Introduction}

Intestinal parasitic infections are major public health problems in developing countries. It is estimated that, worldwide, 3.5 billion people are affected by intestinal parasites, and 450 million people, majority of them are children [1].Intestinal helminth infestations are the most commoninfestations among school age children and they tend tooccur in high intensity in this age group [2].

The distribution of these infections is mainly associated with poor personal hygiene, environmental sanitation and limited access to clean water [3]. Many epidemiological researches carried out in different countries have shown that poor sanitary and environmental conditions are associated with intestinal parasitic infections[4]. Vikram et al, also mentioned that poverty, illiteracy, poor hygiene, lack of access to potable water and hot and humid tropical climate are the factors associated with intestinal parasitic infections [5].Bayissa found unsanitary sewage disposal is associated with these infections [6]. This finding is also observed by AlShammari et al, in Riyadh, Saudi Arabia water storage andopen sewage disposal were statistically associated with parasitic infections $(P<0.05)$ [7]. Self-latrine care, lack of solid waste collection and visible sewage near the house are found to be significant risk factors for intestinal parasiticinfections [8].

Ezeagwuna et al, conducted a study in Ozubulu, Anambra State, Nigeria on intestinal parasitic infection and they attributed the spread of these infections to the environment and the socio-cultural habits of the people [9].Overcrowding of people in houses is other factor lead to high prevalence of intestinal parasitic infections [10]. The present study was conducted to investigate these environmental factors in relation to intestinal parasitic infections.

Study area and study population

\section{Material And Methods}

The study was conducted in Elengaz area, southern Khartoum, Sudan. The area is populated, mostly, with people from war-affected areas. In addition to overcrowding living, many people lack essential services. Children in the area are vulnerable group to develop infectious diseases. The present study was carried out among primary school children. Using statistical equation, about 500 children were selected from four primary schools by systemic random sample.

\section{Data collection}

Environmental sanitation and water supply data were obtained from parents of children. Stool specimens were collected from study group in the morning and examined by microscope to view different stages of intestinal parasites 


\section{Results}

There was statistical significance between access to potable water in family house and intestinal parasite infection among primary school children (Odds ratio $=5.8$ and 95\% Confidence Interval $(\mathrm{CI})=3.8$ to 8.9) as shown in table 1 . In table 2 , unsanitary solid waste disposal was statistically significant with intestinal parasitic infections among primary school children (Odds ratio $=1.6$ and 95\% Confidence Interval $=1.1$ to 2.3 ). Also the presence of latrine in the family house as well as number of house rooms were significant with intestinal parasitic infections (Relative risk $=3.9,95 \%$ Confidence Interval $=2.7$ to 4.3$)(\mathrm{P}$-value $=0.004)$ respectively as in tables 3 and 4 .

Table 1: Relationship betweenaccess to potable water in family house and intestinal parasite infection among primary school children in Elengaz, Khartoum, Sudan

\begin{tabular}{lcccccc} 
& \multicolumn{5}{c}{ Intestinal parasitic infections } & \multicolumn{2}{c}{ Non-infected } \\
\cline { 2 - 6 } Water source & \multicolumn{3}{c}{ Infected } & No & $\%$ & No \\
\cline { 2 - 6 } & No & 277 & 75.1 & 92 & 24.9 & 369 \\
\hline No access & 45 & 34.4 & 86 & 65.6 & 73.8 \\
\hline Access & 322 & 64.4 & 178 & 35.6 & 26.2 \\
\hline Total & & 500 & 100 \\
\hline
\end{tabular}

Odds ratio $=5.8$

$95 \% \mathrm{CI}=3.8$ to 8.9

Table 2: Relationship method of solid waste disposal in family house and intestinal parasite infection among primary school children in Elengaz, Khartoum, Sudan

\begin{tabular}{|c|c|c|c|c|c|c|}
\hline \multirow{3}{*}{ Method of waste disposal } & \multicolumn{4}{|c|}{ Intestinal parasitic infections } & \multirow{2}{*}{\multicolumn{2}{|c|}{ Total }} \\
\hline & \multicolumn{2}{|c|}{ Infected } & \multicolumn{2}{|c|}{ Non-infected } & & \\
\hline & No & $\%$ & No & $\%$ & No & $\%$ \\
\hline Unsanitary & 144 & 70.2 & 61 & 29.8 & 205 & 41 \\
\hline Sanitary & 178 & 60.3 & 117 & 39.7 & 295 & 59 \\
\hline Total & 322 & 64.4 & 178 & 35.6 & 500 & 100 \\
\hline
\end{tabular}

Odds ratio $=1.6$

$95 \% \mathrm{CI}=1.1$ to 2.3

Table 3: Relationship between presence of latrine in the family house and intestinal parasite infection among primary school children in Elengaz, Khartoum, Sudan

\begin{tabular}{|c|c|c|c|c|c|c|}
\hline \multirow[b]{3}{*}{ Presence of latrine } & \multicolumn{4}{|c|}{ Intestinal parasitic infections } & \multirow{2}{*}{\multicolumn{2}{|c|}{ Total }} \\
\hline & \multicolumn{2}{|c|}{ Infected } & \multicolumn{2}{|c|}{ Non-infected } & & \\
\hline & No & $\%$ & No & $\%$ & No & $\%$ \\
\hline Not present & 318 & 85.9 & 52 & 14.1 & 370 & 74 \\
\hline Present & 4 & 3.3 & 126 & 96.7 & 130 & 26 \\
\hline Total & 322 & 64.4 & 178 & 35.6 & 500 & 100 \\
\hline
\end{tabular}

Relative risk $=3.9$

$95 \% \mathrm{CI}=2.7$ to 4.3

Table 4: Relationship between number of family house rooms and intestinal parasite infection among primary school children in Elengaz, Khartoum, Sudan

\begin{tabular}{|c|c|c|c|c|c|c|}
\hline \multirow{3}{*}{ Number of rooms } & \multicolumn{4}{|c|}{ Intestinal parasitic infections } & \multirow{2}{*}{\multicolumn{2}{|c|}{ Total }} \\
\hline & \multicolumn{2}{|c|}{ Infected } & \multicolumn{2}{|c|}{ Non-infected } & & \\
\hline & No & $\%$ & No & $\%$ & No & $\%$ \\
\hline One room & 310 & 66 & 160 & 34 & 470 & 94 \\
\hline Two rooms & 7 & 58.3 & 5 & 41.7 & 12 & 2.4 \\
\hline Three rooms & 5 & 27.8 & 13 & 72.2 & 18 & 3.6 \\
\hline Total & 322 & 64.4 & 178 & 35.6 & 500 & 100 \\
\hline
\end{tabular}

Chi square $=11.22$

$\mathrm{P}$-value $=0.004$

\section{Discussion}

Spread of intestinal parasitic infections in a population is generally associated with water supply and sanitation beside other factors [11]. People who are drinking contaminated water are being under risk of infection with intestinal parasitic infections [12]. In the present study there was statistical significance between lack of access to safe drinking water (Odds ratio $=5.8$ and $95 \%$ Confidence Interval $(\mathrm{CI})=3.8$ to 8.9 ). This due to the fact that contaminated water is a source of majority of intestinal parasites and people become infected when they drink water contaminated with infective stage of pathogen. Shadma et al, reported that drinking impure water is associated intestinal parasitic infections among children ( $p$ value $=0.001$ ) [12]. Asrat et al, in Ethiopia also found that unsafe drinking water was statistically significant with these infections in school 
children [13]. Children using source of drinking water as tube well had significantly higher prevalence of parasiticinfestation than using tap water[2].

The significance of unsanitary disposal of solid waste in spread of intestinal parasites was revealed in this study (Odds ratio $=1.6$ and $95 \%$ Confidence Interval $=1.1$ to 2.3 ). Indisposed or unsafe disposal of solid waste lead to breeding of house flies and cockroaches which are vectors of some intestinal parasites, in addition to risk of cross contamination of water and food by infective stages of these parasites. Available literature indicated the relationship these infections and incorrect disposal of waste.

House flies and cockroach are increasing in houses where there is no hygienic mean of human excreta disposal i.e. sanitary latrines. Most of infected children in this study were lack latrines in their houses (Relative risk $=3.9$ , $95 \%$ Confidence Interval $=2.7$ to 4.3 ) . in a study conducted in India, latrine was found to be significant risk factor for intestinal parasitic infections [8].

Gastro-intestinal parasitic infections, including soil-transmitted helminths are widespread in crowded urban environments with poor sanitation[14]. In our study overcrowding living was observed by number of house rooms in the study area where the family size is usually large. The number of rooms in the house was statistically significant with intestinal parasitic infections ( $\mathrm{p}$ value $=0.004$ ). Overcrowding usually is considered as suitable environment for infectious diseases transmission between individuals.

\section{Conclusion}

Infection with intestinal parasites is still public health problem in children particularly in developing countries. Poor environmental sanitation, improper drinking water supply and overcrowding were risk factors associated with spread of these parasites in the population.

\section{Acknowledgements}

Thanks to associate professor Mohamed Sari Eldin and associate professor Bashir Mohamed El Hassan, University of Khartoum for their continuous Assistance in our research field.

\section{References}

[1] Laura M, Federica B, David D. C, Lucia. E, Gioia C, Domenico Oand Annunziata G. Intestinal parasite infections in immigrant children in the city of Rome, related risk factors and possible impact on nutritional status. Parasites \& Vectors 2012, 5:265.

[2] Ram B. S, Sailesh B, Satish Y, Ratna B, Nilambar J, Paras Kumar P. A study of prevalence of intestinal parasites and associated risk factors among the school children of Itahari, Eastern Region of Nepal. Tropical Parasitology 2013, 3(2): 140-144.

[3] Aschalew G, Belay A, Bethel N, Betrearon S, Atnad Y, Meseret A, Mengistu E and Baye G. Prevalence of intestinal parasitic infections and risk factors among schoolchildren at the University of Gondar Community School, Northwest Ethiopia: a crosssectional study. BMC Public Health 2013, 13:304

[4] Pinar O, Sema E, Berna G, Ozlem O and Erdal B. Intestinal parasites prevalence and related factors in schoolchildren, a western city sample-Turkey. BMC Public Health 2004, 4:64.

[5] Vikram M, Juanita H, Saeed A, Ghazala R, Mohammad A. B. Prevalence and Factors Associated with Intestinal Parasitic Infection among Children in an Urban Slum of Karachi. PLoS ONE, 2008, 3(11): e3680.

[6] Bayissa C. Prevalence of Intestinal Parasitic Infections in Mojo Health Center, Eastern Ethiopia: A 6-year (2005-2010) Retrospective Study. Epidemiol, an open access journal, 2013, 3(1): 119.

[7] Al-Shammari S, Khoja T, El-Khwasky F and Gad A. Intestinal parasitic diseases in Riyadh, Saudi Arabia: prevalence, sociodemographic and environmental associates. Tropical Medicine and International Health 2001, 6(3): 184 - 189.

[8] Manisha M, Anirudhha K, Sachin M, Milind D, Nita G. Prevalence of intestinal parasitic infections and associated risk factors among pre-school children in tribal villages of North Maharashtra, India. International Journal of Research in Health Sciences, 2014, 2(1): $133-139$

[9] D Ezeagwuna, Okwelogu, Ekejindu, Ogbuagu C. The Prevalence And Socio-Economic Factors Of Intestinal Helminth Infections Among Primary School Pupils In Ozubulu, Anambra State, Nigeria. The internet Journal of Epidemiology 2009 vol 9 No 1

[10] Romano N, Saidon I, Chow S. C, Rohela M, Yvonne A. L. Prevalence and Risk Factors of Intestinal Parasitism in Rural and Remote West Malaysia. PLoSNeg1 Trop Dis 5(3): e974.

[11] Zahid H. C, M. AfzalAndMushtaq A. M. Epidemiological Factors Affecting Prevalence of Intestinal Parasites in Children of Muzaffarabad District. Pakistan J. Zool, 2004, 36(4), 267-271

[12] Shadma M, Hemna S, Tabinda A. Frequency and risk factors for intestinal parasitic infection in children under five years age at a tertiary care hospital in Karachi. J Pak Med Assoc, 2009, 59(4): 216 - 219.

[13] Asrat A, Tewodros D and Alemayehu W. Prevalence and risk factors of intestinal parasites among Delgi school children, North Gondar, Ethiopia. Journal of Parasitology and Vector Biology, 2011. 3(5), 75-81.

[14] Rebecca L. Lander,Alastair G. Lander, Lisa Houghton, Sheila M. Williams, Hugo Costa-Ribeiro, Daniel L. Barreto,Angela P. Mattos,Rosalind S. Gibson. Factors influencing growth and intestinalparasitic infections in preschoolers attendingphilanthropic daycarecenters in Salvador,Northeast Region of Brazil. Cad. SaúdePública, Rio de Janeiro, 2012, 28(11):2177-2188. 